\title{
A brief critical approach to Janz's penultimate space model to authenticate experience with the transcendental from a Christian perspective
}

Author:

Raymond Potgieter ${ }^{1}$

Affiliation:

${ }^{1}$ Department of Theology, North-West University,

Potchefstroom Campus,

Potchefstroom, South Africa

Correspondence to:

Raymond Potgieter

Email:

ray@csmdist.com

Postal address:

PO Box 19491, Noordbrug

2522, South Africa

Dates:

Received: 05 July 2011

Accepted: 14 Dec. 2012

Published: 13 Mar. 2013

How to cite this article:

Potgieter, R., 2013, 'A brief

critical approach to Janz's penultimate space model to authenticate experience with the transcendental from a

Christian perspective', In die Skriflig/In Luce Verbi 47(1),

Art. \#107, 8 pages. http://

dx.doi.org/10.4102/ids.

v47i1.107

\section{Copyright:}

(C) 2013. The Authors.

Licensee: AOSIS

OpenJournals. This work

is licensed under the

Creative Commons

Attribution License.

Read online:
Janz proposed a model of authenticity, based on the thesis that the closest proximity possible allows conditions for the Ultimate to become a referential framework within which the transcendental real meets with empirical reality. This is mainly expressed in terms of metaphysical time and space. This model may be usefully employed by religions that claim meeting with the transcendent and wish to do so on a rationally motivated basis. It is the author's belief that this model may be employed by the Christian faith in conjunction with other similar models so that Christianity's unique distinctives of its experience of the penultimate are emphasised.

'n Kort kritiese benadering tot Janz se ruimte model om geloofservaring te kontroleer vanuit ' $n$ Christelike geloofsperspektief. Janz se model is gebaseer op die tesis dat die naaste nabyheid voorwaardes nakom sodat die Uiteindelike 'n verwysingsraamwerk daarstel waarbinne die ware transendentale empiriese werklikheid ontmoet. Dit word hoofsaaklik uitgedruk in terme van metafisiese tyd en ruimte. Hierdie model kan nuttig in diens geneem word deur godsdienste wat aanspraak maak op ontmoeting met die transendente en wat dit op 'n rasioneel gemotiveerde grondslag wil fundeer. Dit is die skrywer se oortuiging dat hierdie model deur die kerk in samewerking met ander soortgelyke modelle gebruik moet word sodat die kenmerkende eienskappe van die Christendom geloof sy unieke ervaring van die voorlaaste kan beklemtoon.

\section{Introduction}

A lot of energy is spent in the search for authenticity. N.T. Wright (1999:86) is in search of a '... crucifiable first-century Jew', a figure called Jesus. One who will emerge as an authentic historical figure regardless of presupposition and predisposed biases. He wants to pursue this quest in the spirit of the 'Third Quest' model. Graves (2008) on the other hand pursues a model unified by its relational complexity as pertains to the human person to explore for instance, the mind. He discards previous models as being simplistic or overly romantic in favour of incorporating the latest insights afforded by physics, biology and religious pluralism (Graves 2008:1-2). This he does by changing the quest of the old to address meaningfulness as a new question and so develops a new model for authentic exploration. Without going into further detail I would suggest that examples of similar models could of course be multiplied to include almost any quest imaginable.

In both these examples the point I want to make is that there is recourse to models favoured to replace previous models and by their very nature I would suggest, as moves towards greater authenticity. For Wright the reason for replacement seems to be the failure of previous searches for the emergent authentic historical Jesus, begging the question of who the Jesus was who was worshiped by the early church (Wright 1999:120). Graves (2008:206-207) on the other hand proceeds from the standpoint of the latest Western insights to a heuristic portrayal of an intertwined constellation of relationships that constitute the possibility of being distinctively human. This replaces previous models and in the light of modern science suggests a model which accords with present scientific perceptions of reality.

Paul D. Janz (2004) is of the opinion that Christians are obligated to responsibly authenticate their metaphysical claims. He attempts to demonstrate this in a studied epistemic tension between rationality and epistemology as foundational to theological cognition. He does that by critically exploring justifications for doing so in the past and constructs a model that emerges from his study of the subject. Whilst useful, it is my contention that this model proves to be too generic for authenticating the uniqueness of Christian reality. I will suggest how it may be critically seen relative to other models commonly available to the Christian community. 


\section{Some views expressed about Janz's model}

God, the Mind's Desire. Reference, reason and Christian thinking (Janz 2004) is an important book. Not least in that it deals with the age-old tension of trying to get polar-opposite persuaded persons to hold meaningful conversations. Or as Hanby (2006:307) puts it '... the meticulous and disciplined prosecution of a bad answer to a good question ... '. He is, however, somewhat critical in his opinion, persuaded that Janz does not satisfactorily justify his own insights (Hanby 2006:309). Bough (2008) on the other hand is seemingly overall not as critical as Hanby, that is, until you come to the final comment of his review. There he states devastatingly that he is of the opinion that Janz never actually escapes the Kantian enclosure. This actually denies the whole rationale of Janz's superbly crafted argument and so, if one is inclined to accept Bough's comments, sends Janz back to the drawing board. I disagree with Bough and am of the opinion that although Janz clearly establishes the Kantian enclosure it is doubtful that it actually complies with his value-free claims as meeting place with the transcendent.

A relational hermeneutic as suggested by Janz is of particular interest to the church. A Christian perspective on the conclusion of penultimacy as the world of creaturely being' (Janz 2004:215) and Christology is that it culminates with meeting the God of the Bible and of creation and with his Son, Jesus Christ. There cannot be a new surprise revelatory experience for the Christian church, a deepening of understanding certainly. But not, I suggest, of the sort Janz proposes in his value-free theoretical space if viewed from a Christian confessional frame of reference. ${ }^{1}$

\section{Overview of the model}

Here I follow the structure of God, the Mind's Desire. Reference, reason and Christian thinking (Janz 2004) itself as it seems to me that the publishers or possibly Janz himself saw the necessity to give a synopsis of his thesis before elaborating upon his complex and involved arguments.

At the outset let me say that there is no doubt that this model is the consequence of thorough and robust reasoning. Janz's language usage is geared towards precision and his clearly defined concepts let him use unfamiliar phrases such as 'things-in-themselves' (Janz 2004:18) creatively along the way. But it can become somewhat confusing. Nevertheless he spares no energy to accomplish what he sets out to do, namely a reconciliation point of antithetical opinions as mentioned above. So what does he accomplish?

In a nutshell a gateway or platform or even an environment. A scientifically verifiable conversation, where god-talk, is done with the integrity of both reason (read immanence of truth) $)^{2}$ and that of transcendence (read revelation), is maintained and verified through robust qualification.

1.Confessions I have in mind are the reformed Protestant confessions such as Westminster Confession of Faith 1646 and the 39 Articles of Religion of 1563.

2.My addition, as truth, in this context, is that ultimate expression in its meaningfulness is tangible and with finality resembling experiential empirical encounters (Janz 2004:20). Therefore a step beyond some mimetic expression.
Let me give a helpful schematic progression of Janz's model, without giving too much detail for clarification: ${ }^{3}$

(1) The classical question: 'How can human discourse refer meaningfully to a transcendent, incomprehensible and hidden God?' The consequence: historical impasse of polarised positions. (2) The question restated: 'Are there any intrinsic obligations to thinking or reason per se?' (Janz 2004:8). The consequence: A Kantian theoretical space is identified. (3) The question answered: Proposed new hermeneutic (Janz 2004:191). The consequence: Hermeneutical space is available in which integrity of rational enquiry and transcendence is referentially maintained so as to allow conversation about the relationality of the penultimate and ultimate.

With this brief schema in mind let me now elaborate with some more detail so as to establish the rationale behind the framework of this model.

From the outset Janz (2004:14) explores the validity of the older polar frame of references and meaningfulness skilfully meandering through models of aesthesis and noiesis, idealism and realism, empiricism and rationalism, antirealism and realism, act and being and so on. For him, this older form of reference, with its continual standoffs, is guided and motivated by the older type of question asked: 'How can human discourse refer meaningfully to a transcendent, incomprehensible and hidden God?' (Janz 2004:1). But spurred on by the epistemological revolution which has been taking place over the last decades affecting even the most polarised of camps on the intellectual landscape, Janz suggests formulating another question. Here I elaborate some so as to add clarity to the question formulated in (2) (see above). The issue is now about searching for a new hermeneutic which will provide integrity for rational address and transcendence. Or formulated as a question: Is there an interpretative framework in which human discourse can maintain integrity speaking truth of a transcendent with finality?

Having dealt with the later polarisations of act and being Janz (2004:13) comes to the rational conclusion that there is no extra-reality outside the traditionally perceived system of reality. No place from which to have a meaningful discussion about God and to maintain integrity of reason. The observer cannot be divorced from the totality of material reality. Now how does he address this to escape from a seeming dead end?

He finds in Bonhoeffer's Act and Being (Bonhoeffer 1996) a step towards resolving the dilemma in particular for Christian thinking (Janz 2004:105). Polarity correctly understood must have a final form. It is expressed as representative of reason as the act of thinking and of the transcendent as the thinking emanating from being (Janz 2004:1-4, 105). But it was Kant who inverted the polarities in thinking which he viewed as impeding progress in philosophy and so addresses the lopsided privileges accorded to polarised positions. To 3.This is my own schema and $I$ do this for ease of comprehension regards the flow of Janz's arguments which are not easily followed. 
mention a single example: Janz (2004:15) mentions Kant's inversion of traditional idealism which, based on sensory phenomena, calls into question reality in the material world and consequently leads to scepticism of empirical realism. Its polar opposite, traditional metaphysical realism, is inverted to transcendental idealism. In this manner Kant brings in a different perspective to any kind of philosophical idealism or anti-realism (Janz 2004:15-16). Although this approach has sometimes been misrepresented, the point Janz makes is that, recent scholarship recognises that it ushers in a point of finality to conversation as regards theological reference. Acceptance of this point allows Janz to get his first major breakthrough for meaningful conversation. It is important because it maintains the integrity of truth and of the transcendent. The theory is in place.

Janz is aware that its weakness is that Kant never developed this beyond a hypothesis, meaning it only allows for a considered possibility of meeting with the transcendent. In other words, only in the sense of mental possession of a theoretical concept but with the status of embracing possibility. It has no ontological reality, yet, to pre-empt Janz: it misses the mark of empirical actuality. Nevertheless in place is a possible theory. The need is now to find if this theory may be translated into terms satisfying the reality of praxis, bringing into the fold of this space the transcendent whilst maintaining integrity of itself and of truth.

Janz finds this in MacKinnon's treatment of tragedy and with some adjustment reaches the end of his argument (finality). The transcendent is encountered in a sense of finality because tragedy is not finally resolved through ethical resolution. It is a position of stasis. Questions do not have answers and it is often wrong to ask questions. So there is no accompanying authority, simply an impasse (Janz 2004:20). In this environment there cannot be a mimetic resolution, no analogy will suffice. The reason being that tragedy allows for mental possession of reality which serves as its own interpretation, consequently there cannot be any resolution. In fact its finality lies in its non-resolution (Janz 2004:22).

With this established the logical consequences of the position are deduced. There cannot be a redemptive explanation, theological or other, and so in this dimension of stasis only discourse of empirical reality of tragedy remains. So Janz has not only created the space for the integrity of truth and transcendence to meet; he anagogically identified a spatial hermeneutic which he claims is empirically verified. That is quite a find. In other words there is no other place where this can happen and to boot there is finality of meaning. The conversation can end. Resolution is possible. Space has been identified where truth and integrity are maintained in meeting with the transcendent, the space created for the ultimate and penultimate.

The next logical step must necessarily be to facilitate this meeting within the space defined. Janz has to transcend the mental construct with all its possibilities and present it in terms of an actual spatial construct so as to facilitate a meeting of reason with transcendent.
Janz (2004:213) now orientates towards his religious persuasion, which is Christian. He wants the 'real'. To that end he is freer in his use of Christian terminology. Within the now identified referential framework of space and the location of the transcendent he moves to establish the relation between penultimate and ultimate. Theology is not deployed between the poles of ultimacy and penultimacy, it is not a linear continuum, rather it is the place where polar opposites ought to be rationally discussed. Though this may be in the sense of confrontation because the space within which it finds itself is referential. Nevertheless, it is there where integrity of reason and of transcendence or revelational integrity is maintained $(2004: 3,23)$. The gospel testifies to this. Without becoming too involved Janz suggests that it is God who effectually stirs the heart by his grace unto himself to ask 'Who are you' (Janz 2004:216). This question begs an answer in empirical terms and his recourse to Bonhoeffer. Asking 'who' is never without values and therefore accompanying prejudice. That is, unless it can be located in a space where the human logos (rationality or epistemology) and the Counter-logos (revelation or Christology $)^{5}$ are found. These conditions are of course met within the aforementioned spatial conditions stated above. Referentially they suggest a hermeneutic that leads man to consider his creation in God's image. A confrontation that leads to the Christ of empirical history (Janz 2004:217). But not in the traditional biblical or confessional sense. Rather in a revelational sense of a Christ who is relationally affected as the one who is the finality of the very revelation of God and God present. This may lead to transformation as revelation of Christ, yet may be unlike that of traditional revelation. There is no closer resolution to the question posed than this transformation. No deeper esoteric depth or mystery is hidden from empirical reality seen in this sense (Janz 2004:220). ${ }^{6}$

\section{Using other models to critically serve as comment on Janz's model}

Janz does not of course stand alone in this type of model. There is some similarity to Graves (2008) who pursues a similar but more material approach in which God has some autonomous space. A material soul (Graves 2008:205-221) is regarded as a possibility of real space for God's presence. But it is in the sense of religious epistemological reality and seen not as intrusion rather a vacuum which exists within the structure of that which defines soul (Graves 2008:219). Janz on the other hand goes further suggesting the possibility of a meeting of intrusion based upon intrusion.

My main caution about Janz's penultimate and transcendence model stems from the fact that it is not specifically Christian despite its terminology and concepts. To my mind what he

4. His terminology becomes more recognisable and accessible for the theologian not familiar with philosophical concepts. But that does not mean that he restricts himself to the usual content of concepts. For example his understanding of repentance is in the sense of 'genuine repentance' brought about by the new context that he is in the sense of 'genuine repentance'
defining and arguing for (Janz 2004:212).

5.1 bring these concepts together for ease of understanding (Janz 2004:203).

6.This is reminiscent in one sense of the immanent and transcendent polar God of panentheism who is continually being renewed on the empirical continuum, changing but not changing. 
says might as easily apply to the spirituality of most or any other religion as it does to Christianity. He therefore equates Christianity to other faiths without necessarily honouring its distinct characteristics. In my opinion, this spiritual exercise leans towards a form of pantheology. Whilst this is of value and in no way deprecated, for the Christian church to benefit from such a model there has to be commitment to its particular distinctives and not just a mere Christianised substitution of vocabulary.

For all their strengths and limitations I want to suggest that there is a range of models, though variously expressed and differing in specifics, which similarly or in a divergent manner explore the meeting between the penultimate and transcendent. One has a choice of various models such as Teilhard's omega point, Tillich's ground of being or Rahner's anonymous Christianity, Mbiti's inclusive approach to religion in Africa to name a few. I therefore chose some models that I believe might usefully serve as comment on Janz model. The method I will follow will by its very nature focus on some distinctives relative to a penultimate transcendence model. At the conclusion of this study I trust that these heuristic pointers will show that Janz's model may in fact be a useful springboard for the Christian church's continued exploration of its distinctive spirituality.

I start with the concept of mysterion and its usefulness in general spirituality. The next model, also though not necessarily Christian, readily captures Christian interest. It deals with the novel study of Umberto Eco's search for the authentic proto-perfect language (Eco 1997) for perfect communication. Eco highlights the fact of the fallacy of such an original proto language. It therefore remains a challenge to identify an authentic platform where, for instance, science and theology can meet with both maintaining their respective distinctive identities. Then Keith Ward's version of a suggested model of panentheistic Christian reality will be touched upon. Especially the particular manner in which he seeks to allow for a spiritual concept of deity that will meet the minimum Christian expectations as to interpretively meet the inflexible demands of material science. A fourth model will be that of Albert Wolters's emphasis upon specific spiritual dynamism of direction and goal towards which mankind is moving. Wolters' thesis allows for the importance of historical spiritual chronology for god-talk to verify historical authenticity. Finally I want to briefly touch on C.S. Lewis' use of his moral argument in establishing a ready frame of spiritual self-reference, a perspective which I think may be usefully employed to the concept of penultimate.

I will then wrap this section up by juxtaposing some characteristic of each of these models with that of Janz's model. These will serve as pointers suggesting adjustment or correction. Employment of which will however necessitate further in-depth study so as to formulate a penultimate Christology which will encapsulate the uniqueness of Christianity.

\section{Mysterium and ultimacy do not guarantee Christian spirituality}

The following two models are basically two sides of the same coin and will demonstrate a generic approach to mysterium and ultimacy and do not necessarily identify the uniqueness of Christian spirituality.

The mysterium does not guarantee Christian penultimacy: Mysterium terminology of spirituality and of Christian theology shows the tension of penultimate or transcendent but also that this has been variously addressed in the past. This does not deprecate the particular approach to reason that Janz brings to neither his model nor his comments about sacramentalism and its limits.

From the time of Augustine the Greek word mysterion has been readily interchanged with the Latin sacramentum and by the time of Aquinas they are used synonymously (Deneken 2000:996). There is not just a polar tension which does not allow for resolution, rather the focus is upon man in relation to God or in some sense to the 'other'. Historically this is, for instance, encountered in Aquinas' analogous mysterium which he shows is not the prerogative of Jew or Christian. Whilst the former may not apprehend it in terms of being particularly defined, the latter does so in context of the Christian church to reveal the mystery of Christ (Summa Theologiae III q. 60, I, ob. 2. quoted by Deneken 2000:996). Common spirituality is therefore established, a realm that is there for all to access. Continuing on the general religious track Kramer and Gawlick (2003:134-136) in discussing Buber's 'eternal Thou' suggest that only some glimpse of the 'eternal address' may be had. Nothing more than a glimpse. For Buber God is not just abstract but personal 'God is the mysterium tremendum that appears and overthrows, but he is also the mystery of the self-evident, nearer to me than my I' (quoted in Kramer \& Gawlick 2003:134-135). This establishes an emphasis on the proximity of presence.

Aquinas and Buber remind us that spirituality and presence of the 'other' may be shared by Christian and pagan alike. The question for the Christian is of course how to meet with the distinctive Christian God? Janz seems to suggest that meeting with the transcendent will be the consequence of his self-referential penultimate space. From the Christian perspective the way to God is through Jesus Christ (Jn 14:6). Now Janz seemingly will not dispute that. But sees the self-referential hermeneutic governing his Christological encounter with the 'Counter-logos' (Janz 2004:201-202). And here lies the danger. It thus allows for a spirituality which re-interprets the human logos (read Church and Christian perceptions of Logos). This pantheological changing deity denies the validity of God's revelation to mankind and so the canon of Christian scriptures is simply put on hold. For Janz presence may take on identity. Christians do believe that God awaits the 'essential deed' encounter of man in awe in relation to Himself (Biemann 2002:184). But they do so in the context of reliance upon the special revelation given to them by the same God. One has to conclude that you may just as well substitute 'counter logos' for 'counter Allah', 'counter 
Buddha' or 'counter avatar' or even counter reality. What applies to Christianity must apply to any other spirituality. In other words I want to caution that this model needs clear a Christian definition of the parameters of its particular spirituality if it is to be usefully employed by the Christian church. This leads to the next model.

Concluding with proximity not necessarily a Christian ideal: Semiotist Umberto Eco by way of his study of the search for the original perfect language follows a model, which I would suggest is similar in some respect to that suggested by Janz. Unlike a good novel, Eco states the end of the story at the beginning of his book, 'The story of the search for the perfect language is the story of a dream and of a series of failures' (Eco 1997:19). I want to trace in brief this story in search of a generic Ur-language because it has a similar correlation to Janz's search.

Contextually the language story is seen as a legacy of the Bible's Babel (Gn 11:1-9) which served as impetus from time to time occasioning the search for the holy grail of the original Ur-language. Fragmentation however already started taking place before the Babel incident in Genesis 10:31 (Eco 1997:9, 338) and Eco concludes that the original inclusive language therefore contained the seed of its destruction (Eco 1997:352). Succeeding generations have lived with this dissemination ever since. Discovery of a language perfect in all respects would indeed be momentous. It is claimed that it will prove to be commonly intelligible, fully express all meaning(s) and do so without ambiguity, classify all knowledge; in a nutshell serve as the perfect communication medium. In fact it would meet all the shortcomings of present-day and past languages.

Eco $(1997: 1,19)$ purposefully limits his search for the Urlanguage to Europe alone aware of its history of failure eluding discovery by scholars such as Augustine, Descartes, Bacon, Leibniz, the controversial Lull, Dalgarno and Wittgenstein. Nevertheless he explores the catholicity of Latin and English, the validity of Esperanto as auxiliary language and purity of Hebrew and German as languages and the absence of language mediation in Chinese ideograms. Then he dips into the symbolism claims of extreme universalist spirituality as practiced by Rosicurcians and Kabbalists. Finally, he concludes with some comments relevant to language structure and its vestigial remains, but concludes ' ... our story is nothing but a series of failures ...' (Eco 1997:19).

But there is no despair here. Instead he uses some limited pointers provided by universalism in the forms of symbols, artificial intelligence, mathematics and so on, relevant to the present language wave. Eco is of the opinion that it is a move away from actual prototypical language to understanding structural reasoning as mental operations, discerning structured connections between thought and speech - a shift from Ur-language to prototype structure.

Janz's model begins commendably and he provides a seeming resolution to the age-old polar tensions of some of theology's and philosophy's questions. My contention is that Janz did achieve something but not quite what he set out to do, at least not from a Christian perspective. I suggest that careful consideration will show that Janz did not achieve his goal of establishing a value-free penultimate as clearly as he assumes for the Christian church. Proximity of the penultimate within a self-referential framework is not necessarily equated to capturing the elusive transcendent in the first instance and establishing a reference outside of God's sovereignty does not equate to the biblical view of creation. Not when viewed in Christian confessional terms. Proximity may be reached but the hermeneutic that leads to re-interpretation is suspect. If this is true, Janz must then adjust the interpretation of his transcendent and penultimate conclusion to some extent. This will be made clear by the next models which deal more specifically with the inherent content of the model.

\section{Reflecting God in space-time, context, direction and morality}

Whereas the previous models showed that Janz's penultimate and transcendent model does not conceptually guarantee a unique Christian approach, the latter three will address this from a Christian confessional perspective. This approach for instance could have referred to Abraham's canonical theism which follows a format for the development of the account of God in the scriptures tracing creedal formulations, symbolism and liturgical expressions (Abraham 2006:43).

God in space-time: Janz is to be commended that in the penultimate he brings reality as close as is possible to the ultimate. In that self-referential structure ${ }^{7}$ God does not invade reality, merely reveals himself in an a-static environment. Nor is God equated to reality and so he avoids pantheism. But I am not convinced that Janz escapes some panentheistic elements.

Christian panentheist theologian, Keith Ward suggests that the composition of reality is not primarily that of substance, rather a dynamic interaction of 'permanent substratum of changing properties' (Ward 1996:305). Panentheism developed from a philosophical system proposed by A.N. Whitehead and further developed by others. Theologically this system is based upon a polar distinction of God as transcendent and immanent. The transcendent Ultimate (substitute God or deity if preferred) is seen immanently as becoming (substitute changing God or deity). Conversely '... becomings are necessary to the development of God as Consequent. Like any actual entity, God is a process of becoming.' (Honderich 1995:910 quoted in Potgieter 2002:93). So for Ward the polar tensions of dynamic change and nonchange are met in the sufficiency of a bi-polar deity. For Janz this process of becoming takes place in the a-static penultimate. With the consequence that the omnipotent God of traditional Christian theology is repackaged into an incomplete story. Though it too claims to maintain the distinctives of immanence and transcendence.

Insights from material science, such as the uncertainty principle of quantum physics and evolution's randomness in

7.Pieper (1999:8-9) justifies a similar self-referential framework in developing a theory of festivity. But in so doing admits that he enters theological territory (he could have used the word metaphysical). 
natural selection are used to shed light on these irreconcilable attributes particularly with reference to the God of the Bible. Whilst a panentheistic version of reality does recognise the reality of god dynamically involved in reality at the same time wholly removed from it, it is not simply a penultimate moment of self-reference to ultimate reality but a continual process. A Christian model of the meeting of the transcendent and immanent attributes of the God of Judaeo-Christianity is variously expressed in history but in particular in Jesus Christ the God-man (Potgieter 2002:242ff.). Janz's 'counter logos' loses much of its meaning in the space-time incarnation of the Son of God. Jesus is the known entity of the Church's extreme limits (Janz 2004:216) and is so without needing another metaphysical hermeneutic to define the Logos incarnate. For me this is to lapse into mysticism. What may be known about God is to be found in revelation history, understood and applicable today.

In contrast to Janz's self-reference penultimate I would therefore suggest that his concept might be enriched from a Christian perspective by viewing the tensions of transcendence and immanence of God in the incarnation of Jesus Christ. In him the revelation of the transcendent Logos and immanent Logos find their equilibrium.

\section{God in cosmic context and direction}

The Islamic scholar Abdullah Saeed (2008:2) claims reality in terms of cosmic direction and context for the Qur'an with implications for its followers. Quoting the Qur'an has spiritual significance for the faithful, accepted as communicating with God (Saeed 2008:33) - essential in the very understanding of what it is to be a Muslim. Likewise the Judaeo-Christian faith was birthed within the context of revelation.

The Christian faith, if it is anything at all, is a 'book religion,' that is, it is founded upon the inspired teaching of the biblical writers. If it is not this, then it is not Christianity. In the writings of those who reject the biblical foundation of the faith, Christianity, as has been demonstrated time and again, becomes simply a selfprojection of the author. (Reymond 1979:13)

The Bible does not allow for generic theism. Let me explain.

Janz (2004:218) clearly opposes any position that wants to relegate his penultimate way of seeing things as simply another world view. To relegate a world view merely to some truths would be good reason to reject it of course, but not when it serves as metanarrative of the story of the Bible with implications for humankind. Rather it ought to bring out the context of the real of creation in relationship to the Creator. This approach takes into account the single story of the Bible not simply unfolding in history, but interpreting human history (Wolters 2005:124-125).

To make sense of Janz's self-referential framework in a Christian context it must therefore fit in with its metanarrative. Creation's structure and distinctives are 'anchored in the law of creation' or the decrees of God at creation (Janz 2004:59). Intrinsic to this structure is its proximity to God expressed as being direction toward or away from God (Janz 2004:59).
This dynamic concept of direction is not apophatic, but a simple hermeneutic for correctly interpreting created reality and history, that is time and space. It is within the confines of the Bible that concepts such as sin and redemption, world and recreation, kingdom of God and kingdom of Satan and so on find meaning and are validated for a Christian world view expressing creational and not acosmic reality. The Christian church may interpret material and spiritual realities variously but it is not a bipolar reality of unrelated compartments (Schaeffer 1970:102). So what we have here is a distinct and peculiarly biblical approach. Failure to take this into consideration would point to a generic religious model of spirituality as proposed by Janz.

Wolters' model therefore allows for material and spiritual conflicts in which people and God are engaged. These are expressed dynamically in God-man and man-God relationships (Wolters 2005:85). There is therefore more to the meeting with the God of the church than Janz implies if it is to comply with biblical revelational integrity. A Christian world view of necessity takes the fall and man's inclination towards enmity in his relationship with God into account. Consequently, there are spiritual claims related to sin and the devil. God's answer for the sinner is of course redemption; the price paid by His Son, Jesus Christ. Anything less is to be captive to an epistemic philosophy rather than to Christ (Col 2:8). To be fair, Janz (2004:218) refers to Colossians 3:2 to illustrate the unity of reality in penultimacy but the existence of a value-free environment is an eschatological concept in Christian understanding of the totality of reality based upon God's initiative. Now this does not deny similar dynamics as may be claimed by other religions claiming movement towards ultimate and penultimate, nor to deny claims of statism. Piper (2003) expresses this historic relationship with God culminating in the return of Christ as desiring God.

\section{Morality as a self-referential context}

C.S. Lewis is clear that he does not argue for a particular brand of Christianity but comes from the position that the reality of the human mind is that it is capable of comprehending real truth, goodness and beauty. He likens Christianity to a building (Lewis 2002:12) in which the various rooms represent different brands of Christianity, accessible from a common hall. The point is that it is a single building, a single reality within which there is a search on for God. I think that Janz would agree with him for penultimacy is a consequence of that search (2004:218). But on the journey fundamental questions should, according to Lewis, truthfully satisfy such implicit questions as 'are these doctrines true: Is holiness here? Does my conscience move me towards this?' (Lewis 2002:xvi). Again, Janz's search and process towards the penultimate allows for rigorous questions to be met.

For Lewis the penultimate leads to the door of morality which opens decently enough for him. But unlike Janz in search of self-referential space to authenticate the proximity to the transcendental, for Lewis God is already resident in the reality of living. There is no parallel universe only a 
single created reality. God is the self-referent, not reality or a dichotomous form thereof. It is the door to His presence that has to be opened unlike a preparation for meeting as with Janz. One could explore the concept of Christian grace at this point and the work of the Holy Spirit. So the door one knocks on should open up to the truth. This preserves integrity and in fact inverts Janz's question 'Who are you?', in that the person knocking is not expecting to be doing the asking, rather the answering.

For Lewis (2002:29) morality serves to authenticate morality as a self-referential door which integrity forces reason to conclude that there is possibility of meeting the ultimate within. It is self-referential because it is independent of cultural differences, personal taste, instinct, education or the creation of rational spatial integrity. Rather it is how God made people and in particular chose a peculiar group of people through whom He revealed His Son and through them He showed the kind of God He is. Not only is Lewis about self-referencing in my opinion, he is about meeting God through encountering Jesus Christ with the possibility of restoring the relationship with God through the forgiveness of sins. Here is no mystical or rational encounter with an unknown mystical logos that will invert all that I know about God. Rather an encounter with the God of the Bible and of time and space. There cannot be a historic reality in which the meeting of reason and transcendence reveals more than Jesus reveals. An encounter with Him will be real and true despite the prejudices due to sin. There is no encounter where sin will not feature in some way or other, not until the full restoration when Jesus comes again. That is the context of Christianity and its direction.

The power of Lewis' approach is that he does not confine himself to a single referential framework. In fact he also regards joy and imagination as equally valid but applicable to particular audiences. I don't think that it is about spatial stasis for Lewis. Not if you come, for instance, from the perspective of a translated imagination. In fact he speaks of a 'baptised imagination', reminiscent of George MacDonald (Dearborn 2006). This is not limited to theology or the metaphysical. Einstein said, 'I am enough of an artist to draw freely upon my imagination. Imagination is more important than knowledge. Knowledge is limited. Imagination encircles the world' (Viereck 1929). The romantics, Wordsworth and Coleridge, had distinct views on the imagination, an instrument leading to meaning, reminiscent of God's activity in shaping the cosmos out of chaos (Barth 2003:1). This should be sufficient to suggest that the self reference suggesting the closest proximity possible to the transcendent has been explored by others coming to similar conclusions but in different ways to Janz.

Lewis is light on a generic portrayal of meeting with the transcendent God, for one maybe by way of morality for another joy and yet another both. The example of the house with a hallway leading into various rooms, according to Lewis, readily allows for a number of rooms to lead into meeting the owner of the house. For Janz being and action come together, creatureliness and desire, '... with the same kind of intensity and depth of attachment that is manifest in
Gethsemane by the very Creator himself become flesh ...' (Janz 2004:219). Lewis, to my mind, could go along with much of this type of desire. But for him the end of desire would be the meeting with the known God through Jesus Christ. It is not about creating the penultimate, or simply applying one of the methods for example joy or morality searching for an invitation to that meeting. Rather a reality so real that I know myself and my world to an extent I have never been able to, true God-initiated transformation. But to my mind that is not the primary issue for meeting with the Christian God. Knowing yourself and the world you live in more adequately with the consequences of meeting with God. Rather, at another level, there will be the focus on worship and adoration, fulfilment of desires to glorify the Lord.

Janz is all about a rigorous construction of his penultimate model. Conditions are tried and measured to establish and guarantee integrity so as to conclude with a self-referential framework. Lewis takes the tack of humanness and coming to God who is His own self-referential. I would suggest that this pointer must serve to cause Janz to ponder about a corrective which could serve to accommodate God and not only his rational integrity. This is thinking within terms of a scriptural confessional framework making possible the maintenance of the integrity of the God who welcomes sinners through Jesus Christ his Son.

\section{Summary of some pointers}

There is no doubt in my mind that whilst Janz may claim some Christian validity for his model it fits more easily into a generic religious context. If that religion holds to the possibility of a meeting between the penultimate and transcendence, then this rigorously argued model will be useful. It does, in my opinion, satisfy most generic metaphysical requirements based upon robust epistemology but finally concludes in a structure with pantheological strains rather than a unique Christian model.

The mere fact (1) of the presence of spirituality manifested for instance as mysterium is not sufficient guarantee for a spiritual encounter with the God of the Bible. Some corrective to Janz's model must be brought about to guarantee this spiritual encounter will lead to the Christian God. Transcendence, ultimate and so on merely translate to metaphysical concepts with the possibility of relating to being in a wider or narrower sense without defined identity. Such a generic search is echoed by the limits Eco's search for the perfect language showed. It also showed how concepts remain fixed in the community's collective consciousness. This ought to serve as pointer to Janz that the 2000-year-old Christian community has recourse to its own consciousness but especially to a special revelation from which many of its innate ideas stem and remain fixed serving to influence thinking in terms of that reference. A move towards a new concept of Christian epistemology must proceed from within its context of special revelation and not be consequential to the justification of creative reasoning alone.

Panentheism on the other hand (2) showed Janz's logical rigour in avoiding a blend of the transcendent and immanent 
encounter to make it more than referential an encounter. But the revelation of God in Jesus Christ is not sufficient for his suggested encounter within the penultimate. Jesus is the incomplete story of God for the believer and his reality until an encounter within this self-referential framework. I think that for me this would probably rank as the first and foremost criticism of Janz's model. It does not accept the revelation of Jesus, as God-man, as final and true. Here some serious rethinking is necessary if this model is going to address the very heart of Christianity.

Janz is (3) very thin on context outside of the mainly philosophical pursuit of his construct toward a model of the penultimate. But surely a pointer must be the chronological contextual story approach of the Bible. Within that context Christian and Jew both claim God-talk and God-story within the wider metanarrative interpretive of present, past and future. This is of enormous significance. Despite his concern for his own integrity there seemingly is no concern for the veracity or even cognisance of the integrity of the JudaeoChristian story of revelation in space and time. The advantage is of course that this allows him the freedom to establish a framework which is self-referential in which even Jesus must redefine himself outside of history so as to return back into it. But what guarantee is there that he will not have to redefine himself again and again with each following encounter? Is there therefore a final 'counter-logos?' Any Christian would be hard-pressed to apply this model to, for instance, the early Christian martyrs and the mission of the Church using this approach.

Wolters (2005) highlights the dynamism of movement toward or away from God, traced to the Fall.

Consequently Janz's model would have to seriously consider the prejudice which accompanies man into that selfreferential framework. Even in that rationally defined space in which objectivity and subjectivity, the up and down meet man will be predisposed either toward or away from God regardless of the static frame. Any other view is to make light of Christianity's distinctive view of man and of sin and of the holiness of God.

A final meeting with God (4) is not necessarily only seeking the right conditions as with Janz. The Bible points us to the understanding that it is God who seeks us as well. Whilst morality may simply be a vehicle which Lewis recognises as self-referential, it is there to prompt the person so inclined towards seeking a meeting with the transcendent God. There is a moral referential that accompanies all people where some sense of right and wrong is discerned for no other reason than that it is so. Morality, joy and imagination or a combination of the three may individually or collectively have the same role in providing a penultimate framework. In other words there seem to be other ways of determining a rational self-referent other than the complex transcendent proximity model of Janz.

\section{Conclusion}

Whilst I believe that Janz's God, the Mind's Desire is a useful model, I am not convinced that it complies with a Christian framework of truth relative to the special revelation of God. However my comments above could serve, in a heuristic sense, to adjust this superbly reasoned model of ultimate and penultimate and become one of its models for spirituality. Christian verbiage and reference to Jesus does not swing the spiritual pendulum into proximity of the Church from its rational and philosophic roots. To that end I suggest that his model be seen in terms of pantheology applicable to most religions and if applied in a Christian context its usefulness will be evident taking the findings of this study into account. I finally conclude that there is no guarantee within the framework that he proposes that the meeting predicated, for the penultimate will authenticate a meeting with the Jesus of the Bible.

\section{Acknowledgements}

\section{Competing interests}

The author declares that he has no financial or personal relationship(s) which may have inappropriately influenced him in writing this article.

\section{References}

Abraham, W.J., 2006, Crossing the threshold of divine revelation, William B. Eerdmans, Grand Rapids.

Barth, J.R., S.J., 2003, Romanticism and Transcendence, Wordsworth and Coleridge and the religious imagination, University of Missouri Press, Columbia.

Biemann, A.D., 2002, The Martin Buber Reader, Essential writings, Palgrave MacMillan, New York.

Bonhoeffer, D., 1996, Act and Being, Transcendental Philosophy and Ontology in Systematic Theology, in W.W. Floyd Jr. (ed.), Dietrich Bonhoeffer Works, vol. 2, Fortress Press, Minneapolis.

Bough, E.B., 2008, 'A superb survey of rational and theological '"integrity"', viewed 05 March 2011, from http://www.amazon.com/review/R22KMVVJPQ3AVE

Dearborn, K., 2006, Baptized Imagination: The theology of George Macdonald, Ashgate Publishing Limited, Aldershot.

Deneken, M., 2000, s.v. 'Mystery', in A. Vauchez \& B. Dobson (eds.), Encyclopaedia of the Middle Ages K-Z, James Clarke \& Co, Cambridge, p. 996.

Eco, U., 1997, The search for the perfect language, Fontana Press, Hammersmith.

Graves, M., 2008, Mind, Brain and the Elusive Soul: Human systems of cognitive science and religion, Ashgate, Aldershot.

Hanby, M., 2006, 'Review of God, the Mind's desire: Reference, reason and Christian thinking by P.D. Janz', Modern Theology 22(2), pp. 307-309, 18 April 2006, viewed 25 March 2011, from http://onlinelibrary.wiley.com/doi/10.1111/j.14680025.2006.00320_1.x/pdf

Janz, P.D., 2004, God, the Mind's Desire, Reference, reason and Christian thinking, Cambridge University Press, Cambridge. http://dx.doi.org/10.1017/ CB09780511487767

Kramer, K.P. \& Gawlick, M., 2003, I and Thou, Practicing living dialogue, Mechthild Gawlick writes with Kramer as a 'dialogical partner', Paulist Press, Mahwah.

Lewis, C.S., 2002, Mere Christianity, A revised and amplified edition, with a new introduction, of the three books 'Broadcast Talks', 'Christian Behaviour' and 'Beyond Personality', HarperCollins Publishers, London.

Pieper, J., 1999, In Tune with the World, A theory of festivity, in R. Winston \& C. Winston transl., South Bend, St. Augustine's Press, Indiana.

Piper, J., 2003, Desiring God, Meditations of a Christian hedonist, Multnomah Press, Colorado Springs.

Potgieter, R.M., 2002, 'Keith Ward and Panentheism, An evaluation of Keith Ward's panentheism as a step towards a model for a Christian interpretation of cosmology', PhD thesis, Department of Theology, Potchefstroom University for Christian Higher Education.

Reymond, R.L, 1979, The Justification of Knowledge, An introductory study in Christian apologetic methodology, Presbyterian and Reformed Publishing Co, Phillipsburg.

Saeed, A., 2008, The Qur'an, An introduction, Abingdon Press, Routledge.

Schaeffer, F.A., 1970, The God who is there, Hodder and Stoughton, London.

Viereck, G.S. 1929, 'What life means to Einstein', The Saturday Evening Post, 26 October, p. 17, viewed 29 March 2011, from http://www.saturdayeveningpost. $\mathrm{com} / \mathrm{wp}$-content/uploads/satevepost/what_life_means_to_einstein.pdf

Ward, K., 1996, Religion and Creation, Clarendon Press, Oxford. http://dx.doi. org/10.1093/acprof:oso/9780198263937.001.0001

Wolters, A.M., 2005, Creation Regained, Biblical basics for a reformational worldview, (with a postscript by Michael W. Goheen) 2nd edn., William B. Eerdmans, Grand Rapids.

Wright, N.T., 1999, Jesus and the Victory of God, (Christian origins and the question of God), vol. 2, Society for Promoting Christian Knowledge (SPCK) Publishing, London. 